\title{
A PRELIMINARY LIST OF MOSSES OF THE BOTCHINSKY STATE NATURE RESERVE
} (RUSSIAN FAR EAST)

\author{
ПРЕДВАРИТЕЛЬНЫЙ СПИСОК МХОВ БОТЧИНСКОГО ЗАПОВЕДНИКА \\ (РОССИЙСКИЙ ДАЛЬНИЙ ВОСТОК)

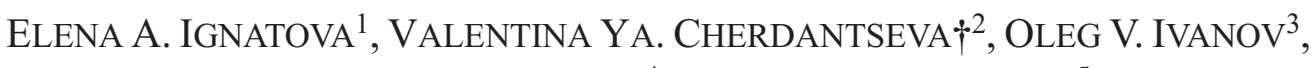 \\ IRINA V. KOSTOMAROVA ${ }^{4} \&$ MICHAEL S. IGNATOV 5 \\ ЕЛЕНА А. ИГНАТОВА ${ }^{1}$, ВАЛЕНТИНА Я. ЧЕРДАНЦЕВА $\uparrow^{2}$, ОЛЕГ В. ИВАНОВ ${ }^{3}$, \\ ИРИНА В. КОСТОМАРОВА ${ }^{4}$, МИХАИЛ С. ИГНАТОВ
}

Abstract

\begin{abstract}
A preliminary annotated list of the moss flora of the Botchinsky State Nature Reserve in Khabarovsk Territory of the Russian Far East includes 239 species, two of which are included in Red Data Book of the Russian Federation. Rhizomnium hattori is newly recorded for Russia. The East Asian elements are rather restricted in the study area, while a number of species common in Sakhalin, the Kuril Islands and Kamchatka, but rare or absent in the mainland southern Russian Far East, are well represented.
\end{abstract}

Резюме

Приводится предварительный аннотированный список мхов Ботчинского заповедника (Совгаванский район Хабаровского края), включающий 239 видов, из которых 2 включены в Красную Книгу Российской Федерации. Rhizomnium hattori впервые приводится для России. Отмечается значительная обедненность изученной территории восточноазиатскими видами и, в то же время, представленность целого ряда видов, широко распространенных на Сахалине, Курильких островах и Камчатке, но редких или отсутствующих на материковой части юга российского Дальнего Востока.

KEYWORDS: mosses, flora, biogeography, Russian Far East, East Asia, Rhizomnium hattori

\section{INTRODUCTION}

The bryophyte flora of nature reserves in the Russian Far East is well explored and published by late V.Ya. Cherdantseva (see review of Ignatov et al., 2004). There are rather few nature reserves left where the species composition is still almost unknown, and the Botchinsky State Nature Reserve has been one of them due to difficult accessibility of its territory. The only one small bryophyte collection (14 liverworts and 55 mosses) was gathered in the reserve before, in 2008, by T.O. Chibiryak. It was identified by Cherdantseva and kept in VLA, but remained unpublished. In August 2013, additional extensive collections were done in the reserve, and the present paper summarizes these results.

We explored a northeastern part of the reserve, in the upper Mulpa River and its tributaries, in the vicinity of "Teplyj Klyuch" reserve station (Fig. 1). This is a rather small part of the whole reserve and the rest of its territory is difficult-to-reach in summer because of the absence of roads and trails. This wilderness is appropriate for protection of the Amur tiger, which is monitored by zoologists mainly during long winter periods. However, as our study covers all main types of forests, rock outcrops and wetlands, the resulting list of mosses exceeds 200 species and is likely to be representative enough for this generally poorly studied region.

\section{STUDY AREA}

An overview of geology, landscape, climate and vegetation of the Botchinsky State Nature Reserve is given by Shlothauer \& Kryukova (2005). The study area is situated ca. $120 \mathrm{~km} \mathrm{SSW}$ of Sovetskaya Gavan, at $48^{\circ} 17^{\prime}$ $48^{\circ} 18.5^{\prime} \mathrm{N}, 139^{\circ} 33.5^{\prime}-139^{\circ} 42.5^{\prime} \mathrm{E}$, on the eastern macroslope of the northern part of the Sikhote-Alin Range, at the distance of $15-25 \mathrm{~km}$ from the shore of the Tatar Strait. It is a gentle hilly area with $230-630 \mathrm{~m}$ altitude (Fig. 2), with relatively rare rock outcrops (Figs.3, 5) along the Mulpa River (Fig. 4) and lower reaches of its tributaries. Main types of rocks are volcanic (andesite)

\footnotetext{
1 - Moscow State University, Biological Faculty, Geobotany Dept., Moscow 119234 Russia; e-mail: arctoa@list.ru

2 - Institute of Biology and Soil Science FEB RAS, Stoletiya Vladivostoka Avenue 159, Vladivostok, 690022, Russia

3 - P.N. Lebedev' Institue of Physics of Russ. Acad. Sci., Leninsky 53, Moscow 119991 Russia; e-mail: ivanov@td.lpi.ru

4 - Botchi State Nature Reserve, 28 b Sovetskaya Str., Sovetskaya Gavan, Khabarovsk Territory, 682880 Russia; e-mail: askaiv@yandex.ru

5 - Main Botanical Garden, Russian Academy of Sciences, Botanicheskaya 4, Moscow 127276 Russia, e-mail: misha_ignatov@list.ru
} 


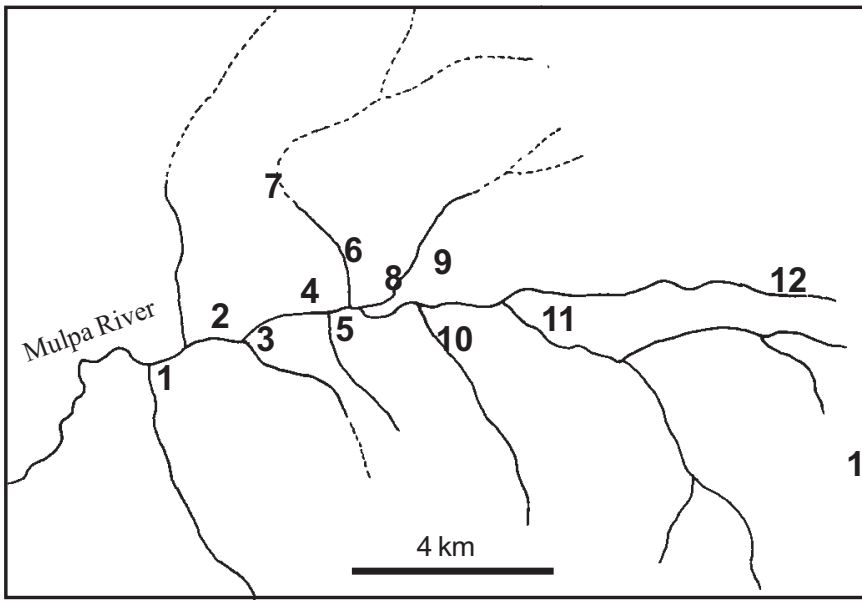

and sedimentary (conglomerates).

The climate of the reserve territory is characterized by cold and dry winter and rather cool and humid summer. The mean annual air temperature is $0.5^{\circ} \mathrm{C}$, mean annual precipitation is $730 \mathrm{~mm}$. The coldest month is January, with mean temperature $-17.5^{\circ} \mathrm{C}$, the warmest month is August with mean temperature $16.7^{\circ} \mathrm{C}$. Frostless period is 128 days. Most precipitation falls in summer.

Vegetation of the northeastern part of the reserve (where bryophytes were collected) is represented mainly by dark conifer forests formed by Picea ajanensis Fisch. ex Carrière and Abies nephrolepis (Trautv. ex Maxim.) Maxim., at places with admixture of Betula lanata (Regel) V.N. Vassil.(= B. ermanii Cham. var. lanata Regel). A considerable part of the study area is covered by spruce and spruce-fir stands recovering from the clear cutting of $1890 \mathrm{~s}-1930$ s, with the tree age of $80-120$ years old. Many stands are quite dense, with trees of 10 to $25 \mathrm{~cm}$ in diameter only, albeit their age may approach to about a century (Fig. 7). Some older stands not rarely have dense younger trees, making forest quite dense as well. Oldaged dark conifer forests of high bonitet which escaped from clear cuttings are rare; they were seen in a few places on north-facing hill slopes. Dark conifer forests comprise a number of varieties, including herbaceous, shrubby and mossy types, the latter being most widespread in the study area.

Broadleaved trees never dominate in the forest: Acer species grow as admixture to conifers, while oak occurs by scattered individials on south-facing herbaceous slopes, reaching its northern boundary in this longitudinal sector.

In dryer and colder places, on flat hill tops, as well as in wide river valleys and in depressions, larch forests of Larix cajanderi Mayr prevail. At the same time, open larch stands are characteristic for Sphagnum mires on gentle hill slopes. Larch forests are fire-dependant and may also develop on hill slopes instead of dark conifer forests. Most common are Ledum types of such forests, with dominance of Ledum hypoleucum Kom.
Fig. 1. Collecting localities in Botchinsky Reserve: 1 - Teryayushchijsya Creek; $2 \& 4-W$ and $E$ of Kamenistyj Spur; 3 - unnamed creek; 5 -Mulpa River opposite the mouth of Mokhovoj Creek; 6-7 - Mokhovoj Creek; 8 Solonchakovyj Creek; 9 road to reserve station; 10 Dlinnyj Creek; 11 - Shapka Mountain; 12 - mire in the upper course of Spokojnyj Creek; 13 - road near pass in upper course of Buryakin Creek.

Secondary birch forests of Betula platyphylla Sukacz. occur at places on terraces of the Mulpa River.

Populus maximowiczii A. Henry stands in the Mulpa River valley are only locally present, as the river is not big enough for them to be extensive, but poplar trunks are very rich in bryophytes.

In creek valleys, Alnus hirsuta Turcz. ex Rupr. and Padus avium Mill. communities are common. Flat bottom of the Mulpa river valley is occupied at places by bush communities formed by Sorbaria sorbifolia (L.) A. Braun, Spiraea salicifolia L., Pentaphylloides fruticosa (L.) O. Schwarz, Betula middendorffii Trautv. \& C.A. Mey., Salix spp., Rosa spp., etc.; they develop after repeated fires and preclude reafforestation. Swampy areas are very fragmentary, near springs on slopes, along streams and in among wet forest and bushy communities. The only extensive open Sphagnum mire, ca. $2.0 \times 0.1$ $0.3 \mathrm{~km}$, was studied on a slightly inclined foot-hill along Spokojnyj Creek (Fig. 6); it has mostly poor fen type, dominated by Sphagnum flexuosum, with scatterred sedge, Calamagrostis spp. and Lobelia sessilifolia Willd. ex Roem. \& Schult., with unique spots were Tomentypnum and Paludula were found as a few indivuduals.

The grouping of moss species by their co-occurence, as has been observed during the field work is as follows:

1. Dominants of the ground-layer in coniferous forests: Dicranum majus, D. polysetum, Hylocomium splendens, Plagiothecium euryphilum, Pleuroziopsis ruthenica., Pleurozium schreberi, Pogonatum japonicum, Polytrichum commune, Ptilium crista-castrensis, Rhytidiadelphus triquetrus, Sphagnum girgensohnii.

2. Trunk bases and litter near exserted roots in conifer forest: Amblystegium serpens, Campylidium sommerfeltii, Dicranum fuscescens, D. scoparium, Echinophyllum sachalinense, Plagiomnium cuspidatum, Plagiothecium curvifolium, P. denticulatum, Pylaisia steerei, Pylaisiadelpha tenuirostris, Sanionia uncinata, Sciurohypnum reflexum, S. starkei, Stereodon pallescens, $S$. plicatulus, Thuidium assimile.

3. Rotten logs and stumps: Brothera leana, Callicladium haldanianum, Campylidium sommerfeltii, Di- 

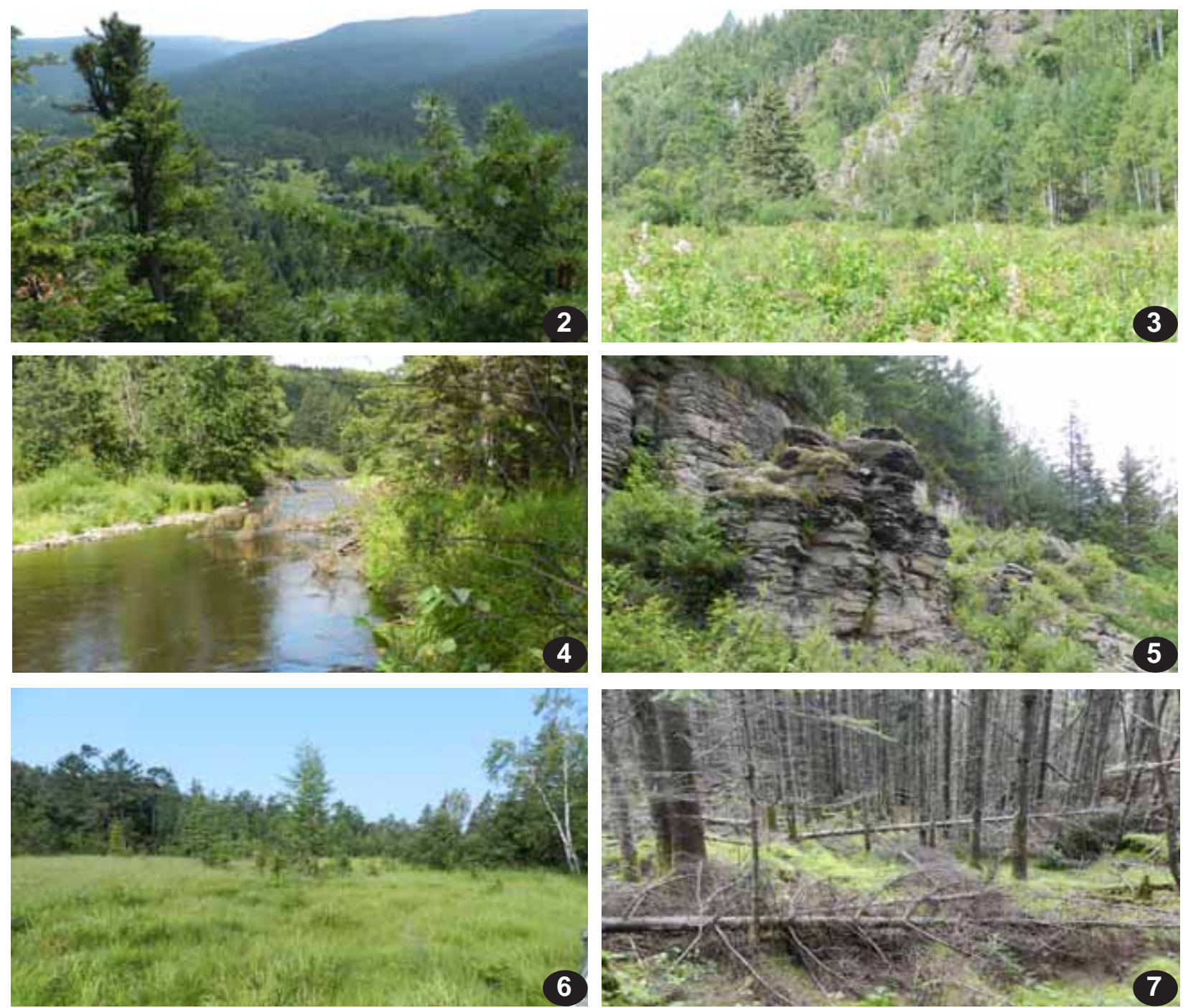

Figs. 2-7. Habitat variety of Botchinsky Reserve: 2 - hilly landscape of Mulpa River valley; 3 - South-facing slope of Kamenistyi Spur, with Spiraea sorbifolia bush in front; 4 - Mulpa River; 5 - dry rock outcrop at Dlinnyj Creek; 6 - mire in the upper course of Spokojnyj Creek; 7 - spruce-fir forest with abundant thin trees.

cranum flagellare, D. fragilifolium, Herzogiella turfacea, Mnium heterophyllum, M. spinulosum, Oncophorus wahlenbergii, Plagiothecium cavifolium, P. laetum, P. latebricola, Platygyrium repens, Rhizomnium magnifolium, R. striatulum, Tetraphis geniculata, T. pelluda, Trachycystis flagellaris.

4. Under upturned roots of fallen trunks: Atrichum flavisetum, Dicranella heteromalla, Pogonatum contortum, P. japonicum, Polytrichastrum pallidisetum, Polytrichum juniperinum, Schistostega pennata.

5. Litter in wet fern-type conifer forests along small streams: Brachythecium baicalense, B. complanatum, Calliergon cordifolium, Cirriphyllum piliferum, Climacium dendroides, C. japonicum, Plagiomnium confertidens, P. ellipticum, Pleuroziopsis ruthenica, Rhodobryum roseum, Rhytidiadelphus subpinnatum, Sciuro-hypnum starkei, S. curtum.

6. Epiphytes of spruce, fir and birch: Anacamptodon latidens, Cryphaea amurensis, Dicranum montanum,
Glyphomitrium cf. warburgii, Iwatsukiella leucotricha, Leucodon pendulus, Neckera pennata, Orthotrichum sordidum, Ulota crispa, U. reptans.

7. Epiphytes of poplar: Anomodon thraustus, Brachythecium rotaeanum, Orthotrichum sordidum, O. speciosum, O. obtusifolium, Pylaisia polyantha, P. selwynii, Zygodon sibiricus.

8. Dry to somewhat more mesic rock outcrops, both exposed and shady: Abietinella abietina, Andreaea rupestris, Aulacomnium turgidum, Brachytheciastrum trachypodium, Brachythecium buchananii, Bryum argenteum, Claopodium pellucinerve, Cnestrum schisti, Cynodontium strumiferum, Dicranum elongatum, D. leioneuron, Encalypta ciliata, Fabronia ciliaris, Grimmia longirostris, G. pilifera, Haplohymenium triste, Hedwigia ciliata, Lescuraea saxicola, Orthotrichum anomalum, Paraleucobryum longifolium, Pohlia elongata, P. longicollis, Pseudoleskeella tectorum, P. papillosa, Rauiella fujisana, Rhytidium rugosum, Schistidium lancifolium, S. papillo- 
sum, Sciuro-hypnum populeum, Syntrichia laevipila.

9. Mesic to wet rock outcrops, more or less shady: Amphidium lapponicum, Anoectangium stracheyanum, Anomodon minor, Bartramia pomiformis, Bryoerythrophyllum recurvirostrum, Bryoxiphium norvegicum, Bryum capillare, B. moravicum, Distichium capillaceum, Eurhynchiadelphus eustegia, Eurhynchiastrum pulchellum, Fissidens bryoides, Homalia trichomanoides, Hypnum cupressiforme, Isopterygiopsis muelleriana, I. pulchella, Leucodon sciuroides, Myuroclada maximowiczii, Neckera oligocarpa, Oxystegus tenuirostris, Rhabdoweisia crispata, Saelania glaucescens, Sciuro-hypnum plumosum, Thamnobryum neckeroides.

10. Mires: Aulacomnium palustre, Drepanocladus aduncus, Helodium blandowii, Paludella squarrosa, Rhizomnium pseudopunctatum, Straminergon stramineum, Sphagnum spp., Tomentypnum nitens, Warnstorfia exannulata.

11. Stream and brook banks, on soil and rocks: Brachythecium rivulare, Bryhnia brachycladula, Bryum pseudotriquetrum, Calliergonella lindbergii, Cratoneuron filicinum, Dichodontium pellucidum, Fontinalis antipyretica, Grimmia hartmanii, Hygrohypnella ochracea, Ochyraea norvegica, Oncophorus virens, Philonotis fontana, Plagiomnium ellipticum, P. medium.

12. Soil banks along roads and landslides in river valleys: Ceratodon purpureus, Bryum argenteum, $B$. creberrimum, Dicranella subulata, Discelium nudum, Ditrichum cylindricum, D. heteromallum, D. pusillum, Funaria hygrometrica, Leptobryum pyriforme, Oligotrichum aligerum, Pogonatum contortum, P. dentatum, Pohlia proligera, P. tundrae, P. wahlenbergii, Polytrichum juniperinum, $P$. piliferum.

13. Coprophilous mosses: Splachnum ampullaceum, Tetraplodon angustatus.

14. Soil on xeric herbaceous slopes: Bryum caespiticium, Brachytheciastrum trachypodium, Weissia brachycarpa.

\section{LIST OF SPECIES}

The nomenclature follows Ignatov, Afonina, Ignatova et al. (2006). After species name the localites (according to Fig. 1) are given, and then the habitats are characterized. The main set of specimens is in MHA, with extensive duplicate material in MW.

Abietinella abietina $-2,8,10,11$. Relatively rare on soil and rocks on dry rock outcrops.

Amblystegium serpens - 1, 2, 4-6, 8, 10. Sporadic on trunk bases (mostly Alnus and Populus), rotten wood, wet soil and rocks at brook and creek banks, on meadows and along forest roads.

Amphidium lapponicum - 1. In one locality, abundant in cracks of shaded cliffs in larch forest.

Anacamptodon latidens - 5. One finding in a small hole on Alnus trunk, in open larch dominated forest.

Andreaea rupestris - 6, 8, 9-11. On mesic to moderately dry rocks in forest or more rarely on exposed cliffs; most commonly on rock-fields dominated by lichens.
Anoectangium stracheyanum - 1. In one locality, abundant on walls of shaded cliffs at river bank.

Anomodon minor - 2, 8, 10. Moderatly common on various rock outcrops, from shaded overhangs and small ledges to moderately exposed vertical faces.

A. rugelii - 6. On mossy rocks at creek bank.

A. thraustus -1 . On trunks of old poplar trees at river bank.

Atrichum flavisetum - 4, 8, 10, 13. Relatively rare under upturned roots of fallen trunks and on soil banks along roads and on steep shaded slopes under rocks outcrops.

Aulacomnium heterostichum - 1. Single collection on ledge of shaded rock outcrop at river bank, in small quantity.

A. palustre - 1, 4, 8-10,12. Relatively common in all types of wet places: Sphagnum bog, sedge mires, stream sides in forest, occasionally in larch forests with Ledum decumbens.

A. turgidum - 2. In lower part of lichen-dominated rock field on S-facing slope, between rocks.

Bartramia pomiformis - 1-13. Common on rocks and cliffs, deeply shaded to moderately exposed; occasionally also on rotten logs and soil.

Brachytheciastrum trachypodium - 11. Single collection on S-facing rock outcrop, on inclined wall surface.

Bracythecium baicalense - 1, 2, 5, 8. Rather common in fir $\&$ spruce and larch forests on litter and rotten wood, occasionally on trunk bases.

B. buchananii - 1, 2, 8, 10, 11. Rare and not abundant on relatively dry, moderately exposed rock outcrops.

B. campestre - 1. Single collection from rock in larch \& spruce forest.

B. complanatum - 1,2. Several findings on soft litter in conifer forests, more commonly in Mulpa River valley, but also in whatershed areas; growing by few shoots to several square meter in moderately shaded places.

B. dahuricum - 1. In single locality in conifer forest with birch, on exposed roots of spruce.

B. irinae $-4,10$. Two collections on wet soil among grasses in flood valleys of creeks.

B. jacuticum - 3. One collection at base of larch trunk on bank of creek.

B. mildeanum - 4. On soil near small pool in larch forest in Mulpa River valley.

B. rivulare - 1-13. Abundant on rocks in river, creek and brook beds, party submerged; also on rocks, soil and rotten wood on banks of streams and in other various wet places.

B. rotaeanum - 1, 5, 8. Sporadic in mixed forests in flood valleys, mostly on trunk bases of poplar trees, occasionally on exposed roots of spruce and on rocks.

B. salebrosum - 1, 4, 8. Sporadic in flood valleys on soil, rotten wood and litter, rare in conifer forests on slopes.

Brothera leana - 1-3, 11. Several collections from rotten wood in a rather different condition of moisture: on dry open slope with xeric shrubs, in mesic herbaceous larch forest, at low bank of creek mixed with Dicranodontium denudatum and in Alnus stand in flood valley of creek; sometimes abundant on logs or found as a small admixture to other mosses.

Bryhnia brachycladula - 1, 4, 5, 8, 10. Sporadic in Alnus 
and Padus communities in brook valleys, on rotten wood and rocks, occasionally on small pieces of rotten wood in conifer forests on slope along Mulpa River and on soil in wet depression in clearing of spruce \& fir forest in creek valley.

Bryoerythrophyllum recurvirostrum - 2, 10. Rare, on dry exposed cliffs and rock outcrops on S-faced slopes, in small cracks and deep crevices.

Bryoxiphium norvegicum var. japonicum - 1, 5. Abundant at places on shaded cliff walls at Mulpa River bank.

Bryum algovicum -8 . One collection on soil bank on slope at roadside.

B. amblyodon - 2, 4, 11. Rare, in cracks and on small ledges of dry cliffs and rock outcrops on S-faced slopes, and also on wet rocky soil at roadside.

B. argenteum Hedw. - 2, 10. Rare, on soil and rocks at roadsides, in small cracks of dry rock outcrops on S-faced slope; var. lanatum - on soil among grasses on steep dry slope of Kamenistyj Range.

B. caespiticium - 2, 8. Rare, on soil bank at roadside, on rock near road in larch forest and on rocky soil in open birch forest on S-faced slope.

B. capillare - 1, 8, 11. Rare, on rotten wood and rocks in mesic conifer forests and on dry rock outcrop on S-faced slope.

B. creberrimum Tayl. $-8,13$. Two collections: on rocks in creek bed and on crags at roadside.

B. elegans -8 . One collection on rocks in creek bed.

B. moravicum - 11. One collection on rock outcrop in larch forest.

B. pseudotriquetrum - 1, 6, 8, 10, 11. Rather frequent in various wet places: on soil and rotten wood along creeks and brooks and on rocks in their beds, once on pebbly bar of Mulpa River, on wet soil on road and in niches of rather dry rock-field in larch forest.

Callicladium haldanianum - 1, 5, 8. Rare, on rotten wood, stumps and tree bases in mesic conifer and birch forests.

Calliergon cordifolium - 4, 5, 8, 10. Sporadic in various wet places: in small swamp in larch forest and in bushy mire, on wet soil on road, in alder stand in flood valley of small creek and on rocks in brook bed.

Calliergonella lindbergii - 4, 7. Rare, on soil in rocky and hummocky places under Alnus and Padus canopy along small streams.

Campylidium sommerfeltii - 1, 4, 5, 10, 11. Sporadic, on rotten wood in Alnus and Padus communities along small streams, occasionally on rotten logs in mesic conifer forests and on rocks in creek beds, above water.

Ceratodon purpureus - 2, 4, 5, 8, 10-13. Rather frequent but not abundant, on various rock outcrops and soil banks on roadsides, on soil among grasses on steep slope, and on wet road; in dry and wet places.

Cirriphyllum piliferum - 8. One collection on litter under ferns in opening in spruce forest (with Rhytidiadelphus subpinnatus).

Claopodium pellucinerve $-1,2,5,8,10,11$. Frequent but not abundant, on mesic and dry rock outcrops in conifer forests on hill slopes and in river valley, on rock walls and in cracks.

Climacium dendroides - 4, 7, 10. Sporadic, in Alnus and
Padus communities along small creeks, on wet soil and rocks.

C. japonicum Lindb. $-1,8$. Rare, on rock at river bank and on soil in wet depression in conifer forest.

Cnestrum schisti - 1, 10, 11. Sporadic on shaded and exposed rock outcrops, in small cracks and deep crevices.

Cratoneuron filicinum - 2, 4, 8. Abundant at places on rocks in creek and brook beds, occasionally on wet rocky soil along roads.

Cryphaea amurensis - 1. Single collection on thin twigs of spruce on Mulpa River bank.

Cynodontium asperifolium - 1, 2, 6, 8, 10, 11. Frequent on ledges and in cracks of shaded rock outcrops on hill slopes and in river valley, occasionally on rock-fields, upturned roots of fallen trunks and dry rotten logs.

C. strumiferum - 2, 8, 9, 13. Sporadic on mossy rock-fields in conifer forests and on shaded rock outcrops, on rock surface and in niches.

C. tenellum - 1, 2, 8, 11. Sporadic on rock outcrops in larch forests on hill slopes and shaded crags in river and brook valleys, occasionally on mossy rock-fields, on rock surface and in cracks.

Dichodontium pellucidum - 1, 4, 5. Abundant at places in Mulpa River valley, on inclined walls of shaded rock outcrops covered with soil, occasionally on rock-fields and on rocks in brook bed.

Dicranella heteromalla - 6, 8, 10, 13. Sporadic on soil covering upturned roots of fallen trees in conifer forests, occasionally also at roadside on soil banks and rock outcrops covered with soil.

D. subulata $-8,9,12$. Abundant at places on roads and roadsides, on rocky soil.

Dicranodontium denudatum - 3. One collection in alder community at brook bank, at base of alder trunk near brook course.

Dicranum drummondii $-8,9,12$. Sporadic on litter, soil and rotten logs in mossy spruce \& fir forests.

D. elongatum - 2. In one locality, on mossy rock-field in larch forest at base of hill slope, in niches between rocks and on rotten wood.

D. flagellare-8, 11, 13. At places not rare on vertical walls of rock outcrops in conifer forest, once collected on birch trunk in mixed spruce $\&$ birch forest.

D. flexicaule -9. Single collection at base of spruce trunk in spruce \& fir forest on hill slope.

D. fragilifolium - 1, 5. Rare on rotten wood in spruce \& fir and larch forests on slope to Mulpa River bank.

D. fuscescens $-1,5,8,11,12$. Sporadic on rotten logs, stumps and other kinds of rotten wood in conifer forest on hill slopes and along Mulpa River, occasionally also in niches of rock-field and on roots of fallen trunk.

D. leioneuron - 2. Single collection on mossy rock-field in larch forest at base of hill slope, in niches between rocks.

D. majus $-1,8,10,13$. Rather frequent on litter and soil in spruce \& fir forests on hill slopes, and also on mossy cliffs and rock-fields along Mulpa River bank.

D. montanum - 1, 2, 11. Rare, on fresh logs and at trunk bases in mixed conifer forest and in open birch forest on steep slope. 
D. polysetum - 2, 5, 8. Sporadic in different habitats: on rocky soil in open birch forest on steep slope, on rotten stump in larch forest on slope to Mulpa River, on rock outcrops in larch forest on hill slope and on litter in mossy spruce \& fir forest.

D. scoparium - 1-13. Common on litter and rotten logs in conifer forests on hill slopes, occasionally also on rocks.

D. undulatum $-8,11,12$. Rare, on soil, litter and rocks in spruce and larch forests on hill slopes.

Didymodon glaucus - 1. Single collection on vertical wall of cliff in larch forest on slope to Mulpa River.

D. zanderi-2. In one locality, on ledges and small cracks of dry S-faced cliffs at Mulpa River bank.

Discelium nudum - 8, 9, 12, 13. Abundant at places on forest roads and roadsides on solid bare soil, forming yellowish-green spots of protonema with inclusions of brownish male plants and plants with sporophytes.

Distichium capillaceum - 1,2. Rare, in cracks of dry and mesic cliffs along Mulpa River.

Ditrichum cylindricum - 5, 10, 13. Rare, on soil banks on steep slopes and on walls of rock outcrops covered with soil.

D. heteromallum $-8,9,12,13$. Sporadic on gravelly soil at roadsides.

D. pusillum $-8,13$. Sporadic on gravelly soil at roadsides.

Drepanocladus aduncus - 2, 4. Rare, on wet soil, in semipermanent pools and on wet gravel along forest road.

Echinophyllum sachalinense - 2, 4, 6-13. Common and locally abundant in spruce \& fir forests on hill slopes, mostly on litter and trunk bases, occasionally also in crevices of rock outcrops.

Encalypta ciliata - 5, 8, 10. Rare, on mesic and relatively dry rock outcrops on slopes to Mulpa River, on small ledges covered with soil and in crevices.

E. pilifera -2. In single locality, at base of S-faced dry cliffs, in small cracks.

Eurhynchiadelphus eustegia - 5. Abundant in single locality, on semi-shaded N-faced slope, on volcanic rock (tufa), with Bryoxiphium.

Eurhynchiastrum pulchellum - 1-13. Common and abundant in conifer forests on hill slopes and along river, creeks and brooks, on rock outcrops and rock-fields, at trunk bases, on rotten logs and stumps.

Fabronia ciliaris - 2, 10, 11. Rare, on rather dry rock outcrops, in cracks of cliff walls and on small ledges.

Fissidens bryoides - 1, 4, 8, 10. Sporadic, on bare soil covering upturned roots of fallen trees in conifer forests on hill slopes, on ledges, in cracks and deep crevices of rocks outcrops along Mulpa River, usually in small quantity.

F. osmundoides - 7. In single locality, on rocks in temporarily flooding bed of creek and on rotten wood in larch forest on slope to creek.

Fontinalis antipyretica - 1, 2. Rare, on rocks in brooks and streams.

Funaria hygrometrica - 5, 10. Interestingly this species has been never found in man-made habitats, while it was collected twice on landslide at slope base in virgin forest and on tufa outcrop.

Glyphomitrium cf. warburgii - 1, 4, 6, 8, 13. Common on spruce and fir trunks in coniferous forest, occasionally also on birch trunks, upturned roots of fallen trunk and on crag walls of rock outcrops in conifer forest.

Grimmia hartmanii - 6, 8. Locally abundant on big boulders in small creeks and brooks, 20-40 cm above water, occasionally also on rocks at river bank.

G. longirostris $-1,2,8,10,11$. Sporadic on mesic to dry rock outcrops in forests on hill slopes and along Mulpa River, on separate rocks and on rock-fields along roads and in larch forests.

G. muehlenbeckii-6, 8. Rare, on rocks of rather dry rockfield in open site in forest, on separate rock on wet meadow in creek valley and on rock at brook bank.

G. pilifera -2 . Single collection at base of dry S-faced cliff on bank of Mulpa River, on vertical wall.

Haplohymenium triste - 10, 11. Rare, on rather dry rock outcrops in open places on steep hill slopes, on rock surface and in small cracks.

Hedwigia ciliata - 1, 2, 6, 8-11. Sporadic on rather dry rock outcrops on hill slopes, both open and under forest canopy, on mossy rock-fields in forest and on separate rocks in larch forest.

Helodium blandowii - 4, 6, 8, 10, 12. Sporadic in various wet habitats: in Sphagnum and bushy mires, in alder community in creek flood valley, in wet depression on forest road and on soil along stream.

Herzogiella turfacea - 1, 4, 5, 8. Sporadic in conifer and mixed forests in river and creek valleys, in rather wet places along streams, on small pieces of rotten wood and on logs, sometimes on trunk bases of spruce, usually in small quantity.

Homalia trichomanoides - 1, 5, 8, 10, 11. Frequent on rock outcrops, both under forest canopy and in open sites, on hill slopes and in Mulpa River valley, on vertical and inclined surfaces and on walls of deep crevices.

Hygrohypnella ochracea - 1, 2, 5-8. Sporadic on rocks in river, streams and brooks, in water and above it, in temporarily flooded brook bed.

Hylocomium splendens - 1-3. Very common and abundant in mossy conifer forests on hill slopes and in river and stream valleys, on litter and rotten logs, occasionally on separate rocks and mossy rock-fields.

Hypnum cupressiforme-1, 2, 5, 8, 10, 11. Frequent on mesic and dry rock outcrops and crags in conifer and birch forests on hill slopes and along Mulpa River, on rock walls, ledges, in small cracks, in deep crevices and in niches of rock-fields, once collected on litter in conifer forest.

Isopterygiopsis alpicola $-8,11$. In two localities on hill slopes to Mulpa River, on walls and in cracks of rather dry rock outcrops.

I. muelleriana - 1, 8, 10, 11. Sporadic on rock outcrops in larch forests on hill slopes and along Mulpa River, on vertical walls, in small cracks and in crevices.

I. pulchella-1, 2, 8, 10. Rare, in cracks and niches of rock outcrops in larch forest on hill slopes, on crags along Mulpa River, occasionally also on soil among grasses at base of steep S-faced slope and on soil covering upturned roots of fallen tree in spruce forest.

Iwatsukiella leucotricha 1-13. One of the most common epiphytes on trunks and twigs of Abies nephrolepis, and occasionally on Betula platyphylla and Picea ajanensis. 
Leptobryum pyriforme - 1-13. Common epigeic moss along roads, trails, on landslides, under upturned roots, along brook banks, etc.; sporophytes are very rare.

Lescuraea saxicola $-6,8$. Two collections: on mossy boulder at brook bank and on rocks of rather dry rock-field in open site in forest.

Leucodon pendulus - 1, 5, 6. Rare, found in few places as single plants or very small population, on spruce twigs in valley conifer forests.

L. sciuroides -1 . In single locality, abundant on vertical walls of crags and on ledges and in crevices of rock outcrops along Mulpa River.

Mnium heterophyllum - 1. Single collection on small piece of rotten wood in fir \& spruce forest at bank of Mulpa River.

M. lycopodioides - 1, 5. Rare, in spruce \& fir forest along Mulpa River bank, on vertical wall of separate rock, on soil under rock outcrops and at base of spruce trunk.

M. marginatum $-1,8$. Rare, on rocks in spruce \& fir forest along Mulpa River bank and on rock side wall under rock outcrops on steep slope of hill.

M. spinulosum - 1, 4, 6, 8, 13. Frequent in mossy spruce \& fir forests on hill slopes, on rotten logs, stumps and small pieces of rotten wood, on exposed roots of spruce, occasionally also at bases of birch trunks and on ledges of rock outcrops, on litter in mixed forest along Mulpa River bank.

M. stellare $-1,5,10$. Rare, on rock outcrops and rock-fields in larch forests on slopes to creek valleys, in niches and crevices, also on soil and exposed roots of spruce.

Myuroclada maximowiczii-1,2. Rare, at base of old poplar trunk and on S-faced slope, in mesic conditions at base of cliff.

Neckera oligocarpa - 1, 8. Sporadic on rock outcrops in spruce \& fir forests on hill slopes and on crags along Mulpa River, mostly on vertical walls.

$N$. pennata - 1-13. One of the most common epiphytes on trunks and twigs of Abies nephrolepis and Picea ajanensis and occasionally on Acer ukurunduense.

Ochyraea norvegica $-5,13$. Two collections: on rocks in brook on bottom of small valley and on rocks on bottom of shallow ravine on slope in mossy spruce forest.

Oligotrichum aligerum - 8, 9, 12, 13. Common on bare soil along roads and occasionally on landslides, and very rare under upturned roots of fallen trunks.

Oncophorus virens - 10. In one locality, in alder community in creek flood valley, on decaying sticks and on rocks.

O. wahlenbergii-1, 4, 8, 11. Not rare, but usually not abundant on rotten logs in wet shady to mesic and rather open forests, occasionally also in cracks of rock outcrops.

Orthotrichum iwatsukii - 10. Single collection on dry rock outcrops on open steep slope, on inclined rock wall.

O. obtusifolium - 2. Single collection on trunk of old Salix tree inclined to Mulpa River course.

O. sordidum-1, 2, 4, 10. Rare, on twigs and trunks of Picea and Salix trees along Mulpa River and in conifer forests in creek valleys.

O. speciosum - 1, 8. Rare, on twigs and trunks of spruce and fir trees in conifer forests in river and creek valleys.

Oxystegus tenuirostris - 1, 2, 6, 8, 10, 11. Common but not abundant on rock outcrops and rock-fields in Mulpa River valley and on hill slopes, on vertical walls and in cracks, in niches between rocks and in crag crevices, occasionally on separate rocks along roads.

Paludella squarrosa - 12. Only few shoots of this species were found in Sphagnum mire, in a relatively oligotrophic community.

Paraleucobryum longifolium - 6, 8, 13. Sporadic on rock outcrops and rock-fields in forests, occasionally on dry rotten logs near rocks where it grows.

Philonotis capillaris $-1,11$. Two collections: on pebbly bar at Mulpa River bank and on boulder at stream mouth.

P. fontana - 4, 12. Rather rare, on wet soil and gravel along forest road and on rocks in stream; one collection in Sphagnum mire.

Plagiomnium acutum - 6. Single collection at base of Alnus trunk in alder community along brook.

P. confertidens - 1, 4, 5, 8. Sporadic on soil and litter in mossy spruce \& fir forests, occasionally also on rock outcrops on steep slope of hill.

P. cuspidatum - 1, 8. Locally not rare on rotten wood, litter rocks and poplar trunk bases along Mulpa River and on hill slopes.

P. drummondii - 10. One collection on gravelly soil at cliff base on open steep slope of hill.

P. ellipticum - 1, 2, 10. Rare, in wet habitats: on hummock at river bank, among grasses along brook and on wet soil in alder community in creek flood valley.

P. medium -4-6. Rare, on soil, litter and rotten wood in mossy spruce $\&$ fir forests in creek valleys.

Plagiothecium cavifolium - 1, 2, 4, 8-11, 13. Rather frequent on rock outcrops and rock-fields in conifer forests on hill slopes and in Mulpa River valley, in niches, deep crevices and on ledges covered with soil, rarely on soil on forest floor.

P. curvifolium - 1, 4, 5,11. Sporadic, on rotten logs and small pieces of rotten wood in mossy conifer forests, in niches of rock outcrops and at bases of larch trunks.

P. denticulatum - 1, 6, 8. Sporadic in fir \& spruce forests, on rocks, rotten wood, in niche under spruce roots, between rocks of mossy rock-field.

P. euryphyllum $-4,9,10$. Sporadic on litter and soil in spruce $\&$ fir forests on hill slopes.

P. laetum - 1, 8-10, 12, 13. Rather frequent in fir \& spruce and mixed forests on hill slopes and along Mulpa River, on trunk bases, rotten logs, stumps and small pieces of rotten wood, occasionally on upturned roots of fallen trunks and on walls of rock outcrops.

P. latebricola $-1,8$. Two collections: on small piece of rotten wood in spruce \& fir forest along Mulpa River and on exposed roots of spruce along brook.

Platygyrium repens - 2, 4-7. Sporadic, on alder and bird cherry trunks in Alnus and Padus communities in creek flood valley, at base of spruce trunk and on twigs of fir in conifer forests, on inclined birch trunk in open birch forest on steep S-faced slope.

Pleuroziopsis ruthenica - 1, 6, 8, 12. Sporadic, in conifer and mixed forests along Mulpa River and on hill slopes, on litter, soil and rotten wood. 
Pleurozium schreberi - 1-13. One of dominant mosses of conifer forest floor; also commonly climbing on trunk bases up to $10-30 \mathrm{~cm}$.

Podperaea krylovii - 2. One collection on small rock outcrops in open birch forest on steep S-faced slope.

Pogonatum contortum - 4, 6, 8, 9, 12. Not rare on bare soil along roads, as well as on soil under upturned roots of fallen trunks.

P. dentatum $-8,10,12,13$. Common on bare soil along roads and on landslides, locally abundant on rock outcrops covered with soil along timber-carrying road.

$P$. japonicum - 6, 8, 12, 13. Not rare on soil covering upturned roots of fallen trunks, and also growing on litter and soil in spruce \& fir forests on hill slopes.

P. urnigerum $-5,8$. Two collections: on inclined wall of rock outcrop on slope to Mulpa River bank and on rotten stump in spruce \& fir forest.

Pohlia andrewsii - 5. Single collection on landslide under rock outcrops at base of slope to Mulpa River.

P. bulbifera - 12. Single collection on bare peat in Sphagnum mire, in small quantity.

P. cruda-1, 4, 8-11. Common in a wide range of environments: soil, rock crevices and niches, in open to deeply shaded places.

P. elongata $-5,8,11,13$. Sporadic on mesic rock outcrops on hill slopes and along Mulpa River, in small cracks and in niches, one collection on small piece of rotten wood at crag base.

$P$. filum - 13. Single collection on ledges of rock outcrops covered with soil along timber-carrying road.

P. longicollis - 1, 2, 10,11. Sporadic on mesic and relatively dry rock outcrops along Mulpa River and on hill slopes, in cracks and deep crevices, usually in a small quantity.

P. lutescens -11 . Single collection in spruce \& fir forest on steep hill slope, on a spot of bare soil.

$P$. cf. melanodon - 5. Single collection on ledge of rock outcrops at base of slope to Mulpa River, in very small quantity.

P. nutans $-1,3,4,6-8$. Sporadic in larch, birch and spruce \& fir forests in Mulpa River valley and in creek valley, on soil, rotten wood and roots of upturned tree, occasionally on rock outcrops.

P. proligera $-8,9$. Rare, on bare soil at roadsides.

P. tundrae -8-10, 13. Frequent on bare soil along roads and occasionally on landslides.

P. wahlenbergii - 4, 8. Rare on wet soil banks near brooks.

Polytrichastrum alpinum - 1, 5. Sporadic on mesic and shaded rock outcrops and mossy rock-fields along Mulpa River.

P. longisetum var. longisetum - 3, 11, 12. Sporadic, in various habitats: on soil in alder community along brook, on rock outcrops in fir \& spruce forest on steep slope of hill, on litter in spruce forest and on rather drained sites in Sphagnum mire.

P. longisetum var. anomalum - 1, 12. Rare, on rocks of mossy rock-field in larch forest in Mulpa River valley and on hummocks in Sphagnum mire.

P. pallidisetum $-4,6,8$. Rare, on soil covering upturned roots of fallen trees in mossy spruce forests.
Polytrichum commune - 8, 10. Rare, on soil in spruce and spruce \& larch forests and on roadside.

P. juniperinum $-8,9$. Rare, on gravelly soil at roadside and on soil at spruce $\&$ fir forest edge.

P. piliferum - 9. Rare, on gravelly soil at roadside.

P. strictum - 2. Single collection among rocks of mossy rockfield in larch forest at base of S-faced slope.

Pseudobryum cinclidioides - 1, 3, 12. Sporadic, on wet soil in mesic spruce and larch forests along Mulpa River, in alder community along brook and once collected in wet depression of Sphagnum mire.

Pseudoleskeella papillosa-6-8, 10. Rare, on walls of shady rock outcrops in forest on hill slope, on vertical wall of separate rock in mossy spruce forest and on rocks of rather dry rock-field on glade in spruce forest.

P. tectorum - 8. Single collection on rather dry rock-field covered with lichens on glade in spruce forest.

Ptilium crista-castrensis - 1-13. Sporadic on litter in mossy spruce \& fir forests.

Pylaisia polyantha - 1. Locally abundant on poplar trunks in Mulpa River valley, occasionally also on twigs and trunks of spruce and on inclined trunk of birch.

P. selwynii-1, 2. Locally abundant on trunks of old poplar trees, once collected on Salix trunk at Mulpa River bank.

P. steerei - 10. Single collection on Alnus trunk in alder community in creek flood valley.

Pylaisiadelpha tenuirostris - 1, 2, 7, 11. Sporadic in various habitats: at base of birch trunk, on rotten log, on rocks in dry brook bed and in cracks of rock outcrops at base of hill slope.

Rauiella fujisana - 1, 5, 6, 8, 10, 11. Sporadic, on walls and in cracks of mesic and rather dry rock outcrops on hill slopes, on base of old poplar trunk at Mulpa River bank and at base of alder tree at brook bank.

Rhabdoweisia crispata - 1, 2, 10. Rare, on shady rock outcrops along Mulpa River and on hill slope, on ledges, in deep crevices and on rock walls, once collected on separate rock in larch forest.

Rhizomnium hattori - 8. Single collection on rotten log in spruce forest in creek valley. Newly recorded for Russia.

R. magnifolium - 4, 6, 8, 12, 13. Rather frequent on soil and litter in mossy spruce forests in creek valleys, once collected on rotten stump.

R. nudum - 4. In one locality, on bare soil and small piece of rotten wood in mossy spruce forest.

R. striatulum - 1, 7. Rare, on rotten log laying in oxbow of Mulpa River and on small piece of rotten wood in larch forest in creek valley.

Rhodobryum roseum - 1, 4, 5, 10. Sporadic on soil and litter in wet spruce forests, once collected on landslide on slope.

Rhytidiadelphus subpinnatus - 1, 8. Rare, on soil among Senecio cannabifolia and on rock at bank of Mulpa River, and also on litter in wet spruce \& fir forest in creek valley.

R. triquetrus -1-13. Rather frequent on litter in spruce \& fir forests, and also on rotten wood, rocks and trunk bases.

Rhytidium rugosum -2, 8, 10. Rare, but locally abundant on rock outcrops and rock-fields in larch forests on hill slopes.

Saelania glaucescens - 1, 11. Rare, in cracks of mesic and dry rock outcrops along Mulpa River and on hill slope. 
Sanionia uncinata - 1-13. Rather frequent but not abundant in various mesic and wet habitats: on wet soil, rocks and tree bases along Mulpa River, in bushy mire, on rotten wood in flood valley alder community, once collected on larch stump in Sphagnum mire with open larch canopy.

Schistidium echinatum - 10. In one locality, on walls and in cracks of rather dry rock outcrops on steep hill slope.

S. lancifolium - 2, 5, 7, 8, 10, 11. Sporadic, on mesic and rather dry rock outcrops and cliffs along Mulpa River and on hill slopes, on rocks in temporarily flooded brook bed and in stream course.

S. papillosum - 1, 2, 6, 8, 10, 11. Rather frequent on mesic and dry rock outcrops and rock-fields, occasionally on separate rocks in spruce and larch forests.

S. pruinosum - 2. Single collection at base of dry S-faced cliffs at Mulpa River bank.

S. pulchrum - 1, 8, 11. Rare, on walls and in cracks of mesic rock outcrops along Mulpa River and in conifer forests on hill slopes.

$S$. rivulare -4 . Single collection on rock in stream.

S. sibiricum -2, 6. Rare, on rocks in bush community in flood valley of Mulpa River and on mossy rocks in brook bed.

Schistostega pennata - 1, 6, 8, 10. Sporadic on soil covering upturned roots of fallen trees and also in deep crevices of rock outcrops along Mulpa River.

Sciuro-hypnum curtum - 8, 10, 12, 13. Sporadic on litter and tree bases in spruce and fir forests, locally abundant on litter in old-growth spruce \& birch forest on steep Nfaced slope (13); also on landslide and on rock outcrops at hill slopes.

S. plumosum - 1. In one locality, on walls at base of shady rock outcrops along Mulpa River.

S. populeum - 1, 2, 8, 10, 11. Sporadic on rather dry cliffs and rock outcrops along Mulpa River and on hill slopes.

S. reflexum - 7, 13. Two collections: at base of Padus trunk in brook flood valley and on litter in grassy spruce forest.

S. starkei-1, 2, 5, 8-10, 12, 13. Common in spruce \& fir forests on rotten wood, litter, soil and rocks, occasionally also in larch forests on litter and rotten wood and in crevices of rock outcrops.

S. uncinifolium - 4, 6. Rare, but locally abundant on mossy boulders in Alnus and Padus communities along brook.

Sphagnum angustifolium - 6, 8, 12. Rare, along brook in spruce forest, in wet depression in spruce \& fir forest in creek valley and in Sphagnum mire with Carex and $\mathrm{Ca}$ lamagrostis.

S. balticum - 12. Single collection in sedge-Sphagnum community in mire.

S. capillifolium - 1, 5, 6, 8, 12. Sporadic and locally abundant in wet spruce forests in brook and creek valleys, on soil at base of rock outcrops along Mulpa River and in rather drained sites of Sphagnum mire.

S. compactum - 9. Single collection on soil in wet depression at edge of spruce \& fir forest, near road.

S. fallax - 12. Single collection in Sphagnum mire, in community with Theypteris palustris and Carex rostrata.

S. fimbriatum - 12. On Sphagnum mire, in sedge-Sphagnum sites with Lobelia sessilifolia and on hummock near pool.
S. flexuosum - 12. Frequent and locally abundant in Sphagnum mire, in rather drained places with Saussurea, Theypteris palustris, Carex rostrata and Lobelia sessilifolia, as well as in wet depressions with Carex limosa; also in small forest mire on hill slope.

S. girgensohnii - 1, 6, 8, 10, 12, 13. Rather frequent in various habitats: on forest floor in mossy spruce \& fir, somitemes with Betula platyphylla, and in larch forests, in alder community in flood valley of brook, on inclined surface of rock outcrops covered with soil along Mulpa River.

S. inundatum - 12. In hollows at edges of Sphagnum mire and on sedge-Sphagnum sites with Lobelia sessilifolia, locally abundant.

S. magellanicum - 8, 12. Sporadic, in wet spruce forest in creek walley, on soil in alder community and forming hummocks in Sphagnum mire.

S. obtusum - 12. Single collection in hollow of Sphagnum mire.

$S$. riparium - 12. Common in hollows and along water courses in Sphagnum mire, in sedge-Sphagnum communities.

S. rubellum - 12. Rare, forming hummocks near pools in Sphagnum mire.

S. rubiginosum - 8, 9. Rare, in wet spruce forest in creek valley and in mossy spruce $\&$ fir forest on slopes.

S. russowii-8. Single collection in larch forest in creek valley.

S. squarrosum - 6, 8, 10, 12. Rare, in wet spruce \& fir forest in creek valley, in alder community in flood valley of brook and near pool in Sphagnum mire.

S. teres - 12. Rare, in hollow with Utricularia and in rather drained places with Saussurea, Thelypteris and Carex rostrata in Sphagnum mire.

S. tundrae -8 . Single collection on soil in mossy spruce forest with ferns in Mulpa River valley.

S. warnstorfii - 12. Single collection in Sphagnum mire, on sedge-Sphagnum site with Lobelia sessilifolia, forming small hummock.

Splachnum ampullaceum - 8, 12. Rare, on decayed dung along trail in Sphagnum mire and on soil in spruce \& fir forest near Teplyj Klyuch reserve station.

Stereodon pallescens - 1, 5, 11. Rare, on rotten logs under rock outcrop in Mulpa River valley and in spruce forest with Pinus coreensis on steep slope, and on rock in larch forest on slope to Mulpa River.

S. plicatulus - 1-13. Very common in different types of forests along Mulpa River and on hill slopes, on trunk bases and rotten logs, stumps and small pieces of rotten wood, occasionally on twigs of spruce, and also on walls and in cracks of crags and rock outcrops along Mulpa River.

Straminergon stramineum - 8, 12. Rare, in wet depression on forest road and in Sphagnum mire, on trail and in hollow with Carex rhynchophysa.

Syntrichia laevipila - 2. In single locality, in cracks at base of dry S-faced cliffs on Mulpa River bank.

Tetraphis geniculata -1-13. Rather frequent on rotten logs and stumps, rarely on small pieces of rotten wood in spruce $\&$ fir forests on hill slopes and along Mulpa River.

T. pellucida-1-13. Rather frequent, on rotten logs and stumps in spruce \& fir forests, and also on exposed roots of spruce 
and on soil covering upturned roots of fallen trees.

Tetraplodon angustatus - 1, 11. Rare, on mossy rock-field at base of slope to Mulpa River and on rotten log in larch forest on hill slope.

Thamnobryum neckeroides $-6,8,13$. Rare, on mossy rocks and rock outcrops in spruce \& fir forests on hill slopes.

Thuidium assimile - 1, 5, 6, 8. Sporadic on soil, rocks, litter and trunk bases in mossy spruce \& fir forests along Mulpa River and on hill slopes.

Tomentypnum nitens -12 . Single collection in rather drained site on trail in Sphagnum mire.

Trachycystis flagellaris - 1, 8, 11. Rare, on soil, litter, rotten stump and rock outcrops in spruce \& fir forest along Mulpa River and on hill slopes.

Ulota crispa - 1-13. Frequent on spruce and fir trunks and twigs in conifer forests.

$U$. reptans $-1-3$. One of the most common epiphytes on trunks and twigs of spruce and fir, and occasionally on birch trunks.

Warnstorfia exannulata - 4, 8, 12. Rare, in mires, both of Sphagnum type and in bush communities.

Weissia brachycarpa - 2, 10. Scattered on south-facing herbaceous slope (Kamenistyi Spur), on soil rich in humus, and in small cracks of rather dry rock outcrops on steep slope of hill.

Zygodon sibiricus - 1. Rare, on old poplar trunks at Mulpa River bank.

Although the reserve is not far from the Primorsky Territory where the East Asian moss flora is well represented, we failed to find a number of species quite common in the southern Russian Far East, e.g., Forsstroemia trichomitria, Gollania ruginosa, Haplocladium microphyllum, Schwetschkeopsis fabronia, and Taxiphyllum aomoriense. Other species of the same geographical group, which are very common in a somewhat more southern areas were found in Botchinsky Reserve, but in a single or very few localities: Anomodon traustus, Aulacomnium heterostichum, Brothera leana, Climacium japonicum, Eurhynchiadelphus eustegia, Leucodon pendulus, Myuroclada maximowiczii, Plagiomnium acutum, Podperaea krylovii, Pylaisiadelpha tenuirostris, Rhizomnium striatulum, Thamnobryum neckeroides.

At the same time, the studied flora is rich in species common in Sakhalin (Bakalin et al., 2012), the Kuril Islands (Bakalin et al., 2009), and Kamchatka (Czernyadjeva, 2012), which are rare or absent in mainland Asia (Bardunov \& Cherdantseva, 1982): Brachythecium irinae, Bryoxiphium norvegicum, Discelium nudum, Echinophyllum sachalinense, Grimmia hartmanii, Leucodon sciuroides, Oligotrichum aligerum, Sciuro-hypnum uncinifolium, Sphagnum rubiginosum, Tetraphis genuiculata. This fact obviously indicates that the climate parameters in the study area are more similar to humid Okhotsk region than to more warm and dry Primorsky Territory.
Two species found in the reserve, Cryphaea amurensis and Bryoxiphium norvegicum var. japonicum, are in the Red Data Book of the Russian Federation. The former species is especially interesting, for it has been known earlier only in three areas: in the middle reaches of the Bureya and Zeya Rivers (both are left tributaries of the Amur), and in one locality in the Sikhote-Alin Mountains in Primorsky Territory (foothill of Olkhovaya Mountain). Both in the latter locality and in Botchinsky Reserve, Cryphaea was found in a very small quantity, as few shoots; an expanded search in similar habitats nearby was in vain.

One species, Rhizomnium hattorii, is newly recorded for Russia. It was hitherto reported from Japan (Noguchi \& Iwatsuki, 1989), China and Korea (Li X.-J. et al., 2007).

\section{ACKNOWLEDGEMENTS}

We are grateful to the reserve rangers and administration for help in conducting field work. The work was partly supported by RAS program "World Life, Current State and Development".

\section{LITERATURE CITED}

BAKALIN, V.A., V.YA. CHERDANTSEVA, M.S. IGNATOV, E.A. IGNATOVA \& T.I. NYUSHKO 2009. Bryophyte flora of the South Kuril Islands (East Asia). - Arctoa 18: 69-114.

BAKALIN, V.A., O.Yu. PISARENKO, V.Ya. CHERDANTSEVA, P.V. KRESTOV, M.S. IGNATOV \& E.A. IGNATOVA] БАКАЛИН В.A., О.Ю. ПИСАРЕНКО, В.Я. ЧЕРДАНЦЕВА, П.В. КРЕСТОВ, М.С ИГНАТОВ, Е.А. ИГНАТОВА 2012. Бриофлора Сахалина. - [Bryophytes of Sakhalin]. Владивосток, Изд. Морского гос. ун-та [Vladivostok, Izd. Morskogo Gog. Univ.]. 310 pp.

[BARDUNOV, L.V. \& V.Ya. CHERDANTSEVA] БАРДУНОВ Л.В., В.Я ЧЕРДАНЦЕВА 1982. Листостебельные мхи Южного Приморья. - [Mosses of the South of Primorskij Province] Новосибирск, Наука [Novosibirsk, Nauka]. 208 pp.

[CZERNYADJEVA, I.V.] ЧЕРНЯДЬЕВА И.В. 2012. Мхи полуострова Камчатка. - [Mosses of Kamchatka Peninsula] СПб., Изд. СПбГУЭТУ “ЛЭТИ” [Sankt-Petersburg, Izd. SPbGETU “LETI”]. $459 \mathrm{pp}$

IGNATOV, M.S., O.M. AFONINA \& E.A. IGNATOVA (eds.) 2006. Checklist of mosses of East Europe and North Asia. - Arctoa 15: 1-130.

[IGNATOV, M.S., E.A. IGNATOVA \& G.A. PRONKINA] ИГНАТОВ М.С., Е.А. ИГНАТОВА, Г.А. ПРОНЬКИНА 2004 [2005]. Мхи заповедников России. - [Mosses of State Reserves of Russia] Современное состояние биологического разнообразия на заповедных территориях России. Том. 3. Лишайники и мохообразные. М., МСОП [Sovremennoe sostoyanie biologicheskogo raznoobraziya na zapovednykh territoriyakh Rossii. Vol. 3. Lishainiki i mokhoobraznye. Moscow, IUCN]: 274-366.

LI X.-J., SI HE \& ZANG M. 2007. Mniaceae. - In: Moss Flora of China. Science Press \& Missouri Botanical Garden, Beijing, New York \& St. Louis. 4: 93-144.

NOGUCHI, A. \& Z. IWATSUKI 1989. Illustrated Moss Flora of Japan. Vol. 3. - Hattori Botanical Laboratory, Nichinan, 492-742.

[SHLOTHAUER, S.D. \& M.V. KRYUKOVA] ШЛОТГАУЭР C.Д., М.В. КРЮКОВА 2005. Флора охраняемых территорий побережья российского Дальнего Востока: Ботчинский, Джугджурский заповедники, Шантарский заказник. - [Flora of protected territories of the coast of the Russian Far East: Botchinsky and Dzhugdzhursky Nature Reserve, Shantarsky Wildlife Zakaznik] М., Наука [Mоscow, Nauka]. 264 pp. 